\title{
Production and Characterization of Polymeric Composite Materials Using MDF Waste in Powder and Poliester Terephthalic Resin
}

\author{
Jailton Weber Gomes ${ }^{a *}$, Luiz, Guilherme Meira de Souza ${ }^{b}$, \\ Luiz Guilherme Vieira Meira de Souza Filho ${ }^{b}$, Natanaeyfle Randemberg Santos ${ }^{b}$ \\ ${ }^{a}$ Instituto Federal da Bahia - IFBa, Loteamento Espaço Alfa, s/n, Limoeiro, \\ CEP 42808-590, Camaçari, BA, Brazil \\ ${ }^{b}$ Universidade Federal do Rio Grande do Norte - UFRN, Campus Universitário de Natal, \\ CEP 59078-970, Natal, RN, Brazil
}

Received: October 23, 2014; Revised: August 30, 2015

\begin{abstract}
The growing demand for panels of Medium Density Fiberboard (MDF) for manufacture of furniture produces significant quantities of waste, which is often inappropriate discarded. This paper presents the study of the characterization of a polymeric matrix composite reinforced with powdered MDF residues collected from cuts machines for furniture manufacturing. Samples of the composites having waste mass fractions ( $\mathrm{m}$ ) in the range of $0-20 \%$ in resin Terephthalic (E) were studied. Through mechanical and physical tests the maximum tensile and flexural strength, modulus of elasticity, maximum deformation, composite density and water absorption index were determined. A result of characterization tests confirms the viability of composite when compared to others composites using natural fibers as reinforcement or load.
\end{abstract}

Keywords: polymeric matrix composite, powdered MDF residues, reinforcement, mechanical and physical test

\section{Introduction}

The use of MDF for manufacturing furniture, toys, floors, doors, handicrafts, and other products have become popular because its features are similar to the hardwood, but with some benefits: MDF boards are offered in dimensions, colors and textures that often are similar to natural wood such as jacaranda, cedar, oak and walnut. Furthermore, they present lack of knots and flaws ${ }^{1}$.

The diversification in the use of MDF has been generated significant amount of waste that, although it is often used for some specific purposes, it may constitute a problem of environmental management ${ }^{2}$.

The demand for MDF between 2009 and 2013 reached an average growth of $15.7 \%$ per year, according to portal moveleiro $^{3}$ data. This leads to the conclusion that the waste generated by the MDF manufacturing tends to follow the same development.

The waste generated is presented in the form of swarfs, slivers, shavings and sawdust. The level of pollution caused by such waste is considered low, but when used as a thermal source of energy it releases harmful gases to the nature, contributing to an increase in the global warming ${ }^{4}$.

MDF powder of various particle sizes derived from the manufacture of furniture can be used initially as an alternative for the manufacture of polymeric and ceramic composites, asphalt paving roads and streets and as filler in many products.

*e-mail: jailtonweber@gmail.com
The graph shown in Figure 1 shows that $50 \%$ of the waste generated in the region of Bento Gonçalves is not appropriately discarded, being used as a source of thermal energy or sold, discarded and donated, not adding economic value to them ${ }^{6}$.

In constant search for the reuse of industrial waste, this material emerges as one of the viable ways to manufacture composite materials. The use of wastes to improve the performance of polymeric materials can be evaluated from various aspects such as weight reduction, higher mechanical strength, higher wear resistance, better thermal stability, reduced use of polymers in manufacturing of parts, among others.

The choice to use the polyester resins is because this polymer have low cost, a dimensional stability advantage, resistance to chemically aggressive environments, excellent electrical properties, easy pigmentation, cure in low temperature and using simple molds. This resin is quite used in the production of surfboards, toilet seats, gifts, mannequins and boats?

The wood waste advantageously replace the reinforcements and fillers such as talc, Calcite $\left(\mathrm{CaCO}_{3}\right)$ and fiberglass in the manufacture of polymeric composites due to properties such as low density, low abrasiveness, low cost, moderate hardness and specific resistance, and good mechanical properties ${ }^{8}$.

The use of waste for the formulation of composites has been a priority in the era of sustainable development. The incorporation of industrial wastes for the production of ceramic, metallic and polymeric composites are widely discussed in the scientific literature. 
An extensive search in journals for the use of MDF powder composites resulted in a few articles that prioritize applications in acoustics and materials for construction, and characterizations of the various wood wastes.

The applicability of MDF residue was tested through the manufacture of a table and a box type solar oven. Both manufactured prototypes are being used in the solar energy laboratory of UFRN.

This paper presents the characterization study of a polymeric composite produced with powdered MDF waste. The use of such waste presents features of innovation, especially for its applicability in the manufacture of solar energy prototypes, wind turbine blades and parts for the furniture industry. It can also be used to replace marble and granite stones present in bathroom and kitchen accessories and in the manufacture of parts that does not require significant mechanical stress, such as packaging and tables.

\section{Material e Methods}

\subsection{Materials}

The powdered MDF residue in various particle sizes, showed in Figure 2 and MEV in Figure 3, was collected from a computerized wood cutting machine.

The ortho-terephtalic polyester resin commonly used with 1.5\% Brasnox DM50 (methyl ethyl ketone) catalyst was chosen due to its lower cost, ease of handling and lower temperature requirements.

A carnauba based unmolding agent was used to facilitate the removal of the manufactured parts from the mold during the preparation of specimens.

\subsection{Methods}

To obtain the MDF waste processability and to carry out the tests, the subsequent procedures were followed.

- Separation of impurities using a sieve;

- Production of test samples for the characterization tests;

- Sanding and polishing of the specimens;

- Drying of the specimens in solar greenhouse;

- Mechanical tests, density, water absorption and MEV (Scanning electron microscope);

Figure 4 shows a summary of the steps for manufacturing the composite samples and assays.

For the manufacture of the specimens an iron mold with dimensions of $200 \times 200 \times 8 \mathrm{~mm}$ was used. It was designed in iron in order to allow the pressing of the composite, thus minimizing the amount of bubbles inside.

Table 1 shows the dimensions adopted and the quantity for the samples used in the composite characterization tests.

For the tensile test the ASTM D638-0 $3^{[9]}$ was consulted. It was determined the tensile strength, total elongation and tensile modulus of elasticity ${ }^{3}$. For the flexural test on three points the ASTM D790-10 ${ }^{[10]}$ was used. This test was necessary to point out the characteristics of flexural strength, total elongation, and elasticity modulus ${ }^{4}$.

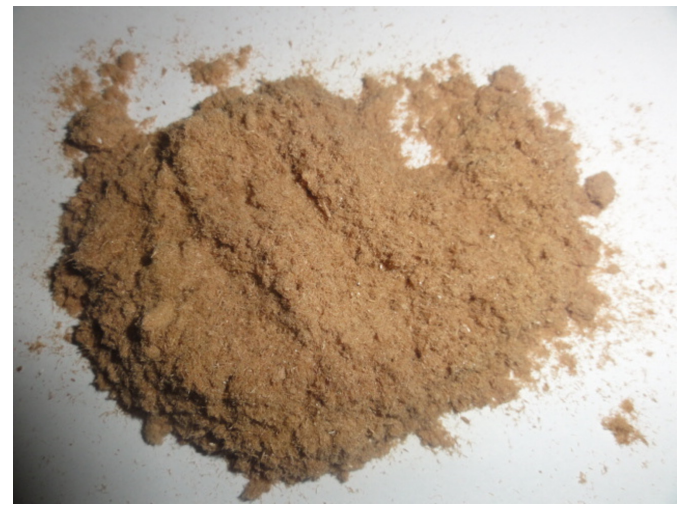

Figure 1. Wood destination and derivatives of Furniture Industry of Bento Gonçalves - RS. Souce: Author.

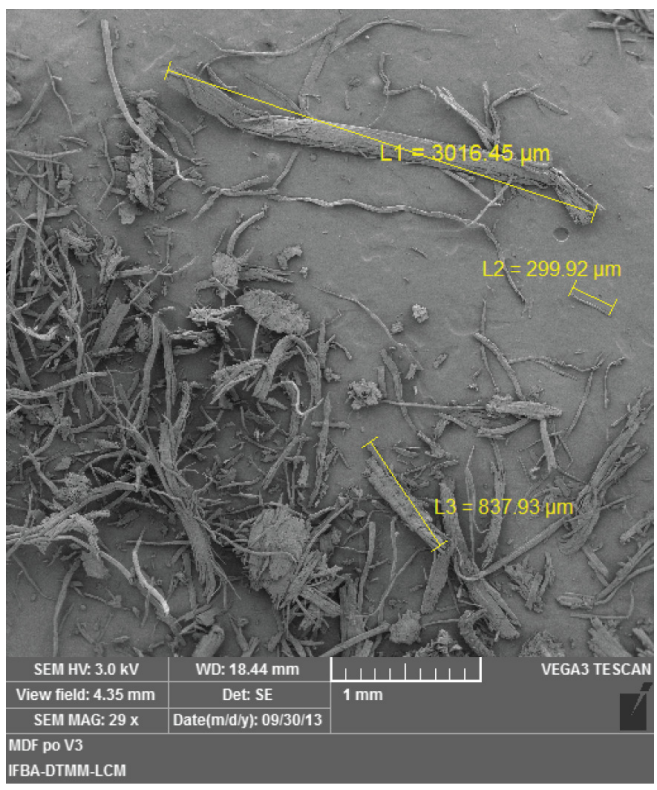

Figure 2. Waste MDF in powder collected in a joinery.

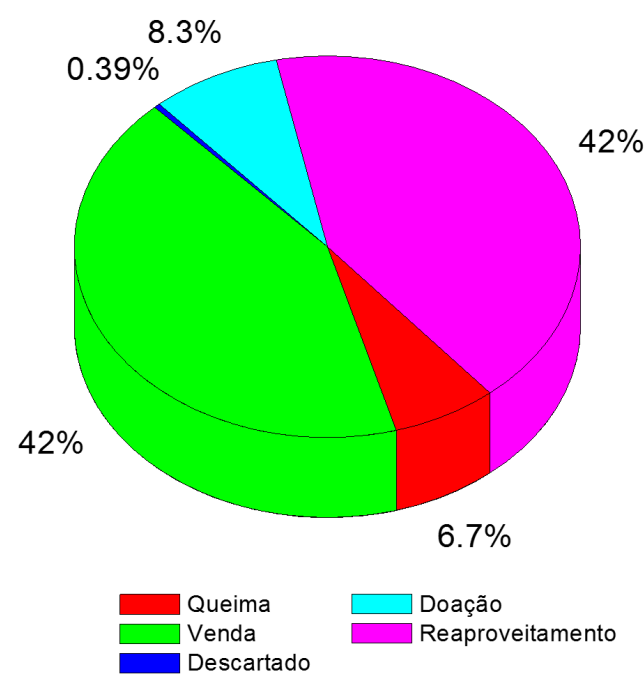

Figure 3. Waste MDF in powder collected in a joinery. Souce: Adapted based on $\mathrm{Koch}^{6}$. 


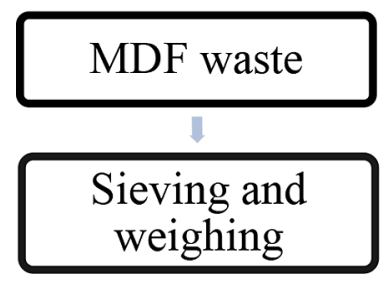

\begin{tabular}{ccccc}
\hline Test & $\begin{array}{c}\text { Nunber of } \\
\text { samples }\end{array}$ & $\begin{array}{c}\text { Length } \\
(\mathbf{m m})\end{array}$ & $\begin{array}{c}\text { Width } \\
(\mathbf{m m})\end{array}$ & $\begin{array}{c}\text { Thickness } \\
(\mathbf{m m})\end{array}$ \\
\hline Tensile/ & $\begin{array}{c}5 \text { units for } \\
\text { formulation }\end{array}$ & 250 & 25 & 8 \\
Flexural & & 60 & 60 & 40 \\
$\begin{array}{c}\text { Density } \\
\text { Water }\end{array}$ & & 50 & 20 & 3 \\
absorption & & & & \\
\hline
\end{tabular}

The density of the material indicates to the designer the mass of the part to be manufactured in the dimensions of the project. To obtain the density of the composite matrices a digital hydrometer DSL 910 with repeatability of $\pm 0.003 \mathrm{~g} / \mathrm{cm}^{3}$ was used.

The degree of water absorption of the studied material was obtained by following the ASTM 570-88 ${ }^{[1]}$ standards. The average values were taken from five samples for each type of manufactured composite. The sizes of these composites are shown in Table 1 and to obtain absorbed portion, Equation 1 was used.

$$
A b s=\frac{P_{f}}{P_{i}}-1
$$

Where:

Abs = Water absorption;

$\mathrm{P}_{\mathrm{i}}=$ Initial mass;

$\mathrm{P}_{\mathrm{f}}=$ Final mass
To calculate the measurement error in the water absorption tests, Equation 2 was used.

$$
\Delta A b s=\left(1+\frac{P_{f}}{P_{i}}\right)+\frac{\Delta P}{P_{i}}
$$

The absorption percent is obtained through Equation 3.

$$
A b s \%=(A b s * 100) \pm(\Delta A b s * 100)
$$

For the analysis of density, tensile test and bending the measurement error is equal to the standard deviation of the samples.

The crystallinity index makes direct influence on material properties such as density, loss of transparency, higher solvent resistance, melting temperature and improves mechanical properties $^{7}$. The index of crystallinity of a material can be evaluated using the Equation 4 based on Segal experience.

$$
I_{c} \%=\frac{P_{(c r)}-P_{(a m)}}{P_{(c r)}} X 100
$$

where:

$I_{c}=$ Crystallinity index in percentage;

$\mathrm{I}_{\mathrm{cr}}=$ Pico de intensidade de difração que representa o material cristalino (eixo y);

$\mathrm{I}_{\mathrm{am}}=$ Diffraction peak intensity that represents the amorphous material (y axis); 
Table 2. Test results of tensile and flexural.

\begin{tabular}{|c|c|c|c|c|c|c|}
\hline \multirow{2}{*}{$\begin{array}{c}\text { Residue's } \\
\text { Concentration }\end{array}$} & \multicolumn{2}{|c|}{ Tensile strength (MPa) } & \multicolumn{2}{|c|}{$\begin{array}{c}\text { Total elongation } \\
(\%)\end{array}$} & \multicolumn{2}{|c|}{$\begin{array}{c}\text { Modulus of Elasticity } \\
\text { (Gpa) }\end{array}$} \\
\hline & Tensile & Flexural & Tensile & Flexural & Tensile & Flexural \\
\hline 0 & 41.57 & 4.72 & 4.17 & 39.23 & 1.32 & 0.04 \\
\hline 10 & 29.42 & 2.84 & 2.92 & 4.08 & 1.33 & 0.06 \\
\hline 15 & 21.45 & 1.89 & 1.89 & 2.29 & 1.87 & 0.10 \\
\hline 20 & 18.57 & 1.23 & 1.79 & 1.89 & 1.19 & 0.17 \\
\hline
\end{tabular}

\section{Results and Discussions}

Table 2 presents the results obtained in the tensile and flexural tests.

In Table 2 it is evident the decrease in the tensile and flexural strength of the composite caused by an increase in the addition of residue. The same behavior occurred in relation to the total elongation, with a decrease in the obtained values. In relation to the modulus of elasticity, a gain was observed with the increase of residue.

The decrease on tensile strength in matrix formulation when compared to the composite with the highest amount of waste, E20, accounted for just under $45 \%$. The same behavior was observed for the flexural strength in comparison to the one showed for the tensile strength, having a roughly four times reduction in strength when compared to the polymeric matrix. In this case the residue function can be considered as load.

The waste introduction gave the composite a lower elongation and consequently a higher modulus of elasticity when submitted to strain. For the formulation E20 the elongation decreased slightly more than two times and the modulus of elasticity increased approximately four times.

In general there was a decrease in the mechanical flexural strength of the composite with the addition of residue. The same behavior was observed when analyzing the total elongation. The introduction of waste resulted in an extreme decrease in elongation and therefore an increase in the magnitude of modulus of elasticity, and in this case the residue can be considered as a reinforcement.

Table 3 shows the density values for all of the manufactured composite formulations.

According to some manufacturers of dark resin, the density can range between 1.10 and $1.20 \mathrm{~g} / \mathrm{cm}^{3}$. The measured density is within the aforementioned range. In relation to the density of the composite, there was not a significant variation in relation to the matrix. There was a variation of around $3.0 \%$ between the formulations and of less than $1 \%$ between the tests. The average density values were $1.23 \mathrm{~g} / \mathrm{cm}^{3}$ with $0.015 \mathrm{~g} / \mathrm{cm}^{3}$ of standard deviation.

The control samples made with ortho-terephtalic polyester resin (dark) without residue were subjected to absorption of distilled water test and Table 4 shows the obtained results.

As expected there was an increase in the rate of water absorption when the residue quantity of the composite was increased. This increase from the matrix or control sample in the formulation with the highest amount of waste, E20, corresponding to almost three times, but still considered low compared to other composites composed of plant fibers it has
Table 3. Resin otho-theraftalic density.

\begin{tabular}{ccccc}
\hline $\begin{array}{c}\text { Composite - } \\
\text { Liquid distilled } \\
\text { Water a 25.5 }\end{array}{ }^{\circ} \mathbf{C}$ & Resin & E10 & E15 & E20 \\
\hline Measured $\left(\mathrm{g} / \mathrm{cm}^{3}\right)$ & $1.20 \pm 0.015$ & $1.23 \pm 0.015$ & $1.24 \pm 0.015$ & $1.23 \pm 0.015$ \\
\hline
\end{tabular}

Table 4. Water absorbtion.

\begin{tabular}{cc}
\hline \multicolumn{2}{c}{ Water Absorption } \\
\hline Material & Abs / \% \\
\hline Resin & $0.904 \pm 0.034$ \\
E10 & $1.686 \pm 0.054$ \\
E15 & $2.008 \pm 0.031$ \\
E20 & $2.346 \pm 0.058$ \\
\hline
\end{tabular}

Table 5. Composite and resin degree of crystallinity.

\begin{tabular}{cccccc}
\hline Material & $\begin{array}{c}\mathbf{I}_{\text {cr }} \\
\text { (u.a.) }\end{array}$ & $\begin{array}{c}\mathbf{I}_{\text {an }} \\
\text { (u.a.) }\end{array}$ & $\begin{array}{c}\text { 2o } \mathbf{I}_{\text {cr }} \\
\text { em graus }\end{array}$ & $\begin{array}{c}\mathbf{2 \theta}_{\text {an }} \\
\text { em graus }\end{array}$ & $\begin{array}{c}\mathbf{I}_{\mathbf{c}} \\
(\mathbf{\%})\end{array}$ \\
\hline Resin & 2156 & 560 & 19.5 & 41.1 & 74.1 \\
E10 & 2092 & 604 & 20.0 & 34.6 & 71.8 \\
E15 & 2116 & 596 & 20.4 & 39.0 & 71.3 \\
E20 & 2076 & 596 & 19.1 & 38.9 & 71.1 \\
\hline
\end{tabular}

absorbed around $5 \%$ of water ${ }^{7}$, orthoftalic MDF composite with $20 \%$ of waste that absorbed $2.8 \%{ }^{[12]}$, other composites composed of plant fibers.

The level of crystallinity was calculated based on equation 3 described by Segal ${ }^{7}$ and the results are shown in Table 5 .

The range of the Theta angle to be observed in the samples corresponds to the interval between $10^{\circ}$ and $60^{\circ}$. When this angle is known, it is possible to reduce the analysis time and the wear on the used equipment.

When the level of crystallinity of the control sample is compared with the composite that showed lower crystallinity, E20, there is a discrepance of 3\%. In some cases, the higher degree of crystallinity, the greater is the mechanical resistance of the material, which was confirmed for the proposed composite. It was also observed little difference in the degree of crystallinity between the composites, suggesting a little influence of the waste on the crystallization of the resin.

\section{Conclusions and Suggestions}

In consonance with the objectives defined for the development of work place were defined conclusions and suggestions for future work. 


\subsection{Conclusions}

1. Demonstrated the feasibility to obtaining the proposed composite made with MDF waste in powder;

2. The MDF residue add to the resin matrix has a charger function when evaluating the tensile strength and flexural, and as reinforcement when considering the increase in the modulus of elasticity in tension and flexural.

3. All formulations tested have the viability to make the composite porposed;

4. The most composite formulation viable was the E20 considering their smaller portion add resin used;

\section{References}

1. Brasil. Banco Nacional de Desenvolvimento Econômico e Social - BNDES. Panorama de mercado: painéis de madeira no Brasil. Rio de Janeiro; 2010. Rio de Janeiro: BNDES; 2010. n. 32. p. 49-90. Available from: <http://www.bndes.gov.br/ SiteBNDES/export/sites/default/bndes_pt/Galerias/Arquivos/ conhecimento/bnset/set32102.pdf>. Access in: 11/10/2014.

2. Hillig É, Schneider VE and Pavoni ET. Diagnóstico da geração de resíduos e dos sistemas de gestão ambiental das empresas do pólo moveleiro da serra Gaúcha. In: Haselein CR, editor. PÓLO moveleiro da serra Gaúcha: geração de resíduos e perspectivas para sistemas de gerenciamento ambiental. Caxias do Sul: Educs; 2004. 165 p.

3. Laureano I. ESPECIAL: Oferta $x$ demanda de painéis de madeira. Florianópolis: Portal do Moveleiro; 2011. Available from: $<$ http://conteudo.portalmoveleiro.com.br/visualiza-noticia. php?cdNoticia=21839\#>. Access in: 06/12/2014.

4. Lima EG. Resíduos gerados em indústrias de móveis de madeira situadas no Pólo Moveleiro de Arapongas. Floresta. 2005; 35(1):15-26.

5. Hillig É, Schneider VE and Pavoni ET. Geração de resíduos de madeira e derivados da indústria moveleira em função das variáveis de produção. Production. 2009; 19(2):292-303. http:// dx.doi.org/10.1590/S0103-65132009000200006.

6. Koch MR. Gestão de resíduos sólidos de uma industria de aglomerados e moveleira: um olhar para sustentabilidade.
5. Adding the residue MDF composite promoted reduction in the use of the resin in $20 \%$ promoting matrix economy.

\subsection{Suggestions}

6. Using other resins as matrices for obtaining diferents composites with the same formulations and make others test;

7. Manufacture other structures using the proposed composite, for example solar and wind prototypes, plus tables, chairs, bookcases and other structures that do not require significant mechanical strength;

8. There were not influence of the waste in composite crystallinity.

[Dissertation]. Lajeado: Unidade Integrada Vale do Taquari de Ensino Superior; 2012.

7. Lion CAPQ. Desenvolvimento caracterização de compósito a partir da Borra da Piaçava para construção da parábola de um fogão solar a concentração. [Thesis]. Natal: Universidade Federal do Rio Grande do Norte; 2013.

8. Correa CA, Fonseca CNP, Neves S, Razzino CA and Hage E Jr. Compósitos termoplásticos com madeira. Polímeros. 2003; 13(3):154-165. http://dx.doi.org/10.1590/S010414282003000300005 .

9. American Society for Testing and Materials - ASTM. D63803: standard test method for tensile properpies of plastic. West Conshohocken; 2003.

10. American Society for Testing and Materials -ASTM. D790-10: standard test methods: flexural properties of unreinforced and reinforced plastics and electrical insulating materials. West Conshohocken; 2001.

11. American Society for Testing and Materials - ASTM. D57088: standard test methods for water absorption of plastics. Philadelphia; 1988. CD ROM.

12. Gomes JW. Obtenção e caracterização de um compósito de matriz polimérica com carga de resíduos gerados pela manufatura do mdf (midium density fiberboard) para a fabricação de um forno solar. [Thesis]. Natal: Universidade Federal do Rio Grande do Norte; 2015. 